\title{
Reproduction of Meloidogyne enterolobii in rootstocks and cucumber hybrids
}

\author{
Silvia Renata S Wilcken ${ }^{\text {; Juliana MO Rosa }}$; Juliana N Westerich ${ }^{1}$; Maria José de M Garcia ${ }^{3}$, Antonio \\ Ismael Inácio Cardoso ${ }^{2}$ \\ ${ }^{1}$ UNESP/FCA, Depto. Proteção Vegetal, C. Postal 237, 18610-307, Botucatu-SP, srenata@fca.unesp.br; ${ }^{2}$ UNESP/FCA, Depto. \\ Horticultura; ${ }^{3}$ APTA-Polo Centro Oeste, Unid. Pesq. e Desenvolv. Bauru, Av Rodrigues Alves 40-40, 17030-000 Bauru-SP
}

\begin{abstract}
This study aimed to determine the resistance of six rootstocks for cucumber (squash 'Menina Brasileira', pumpkin 'Exposição', 'Shelper', 'Tetsukabuto Takaiama', 'B8-A Tetsukabuto' and 'Excite Ikki') and four Japanese cucumber hybrids ('Yoshinari', 'Kouki', 'Taisho' and 'Tsuyataro') to Meloidogyne enterolobii. The experiment was conducted in greenhouse; each plot consisted of one plant per pot containing 2 liters of autoclaved soil. The experimental design was completely randomized, with five replicates per treatment. Two days after transplanting the seedlings, each plant was inoculated with 5,000 eggs and second-stage juveniles (initial population $=\mathrm{Pi}$ ) of $M$. enterolobii. Tomato 'Rutgers' was used as indicative of inoculum viability. Sixty days after inoculated, each plant was evaluated for total number of nematodes in the roots (final population $=\mathrm{Pf}$ ) and reproduction factor $(\mathrm{FR}=\mathrm{Pf} / \mathrm{Pi})$. All rootstocks and cucumber hybrids allowed $M$. enterolobii multiplication, but FR values were lower in 'Shelper', 'Excite Ikki KY' and 'Menina Brasileira' rootstocks. In a second experiment, the low FR in these three rootstocks was confirmed, but with higher values in 'Menina Brasileira'. So, these rootstocks can be recommended to $M$. enterolobii infested areas, but with low populations, because they don't permit great multiplication of the patogen. It is concluded that 'Shelper' and 'Excite Ikki KY' rootstocks had the lowest FR and can be classified as moderate resistant to this nematode.
\end{abstract}

Keywords: Cucumis sativus, Cucurbita moschata, Cucurbita maxima, root-knot nematode, grafting.

\section{RESUMO}

Reprodução de Meloidogyne enterolobii em porta-enxertos e híbridos de pepino

Este estudo teve como objetivo determinar a resistência de seis porta-enxertos para pepino (abóbora 'Menina Brasileira', moranga 'Exposição', 'Shelper', 'Tetsukabuto Takaiama', 'B8-A Tetsukabuto' e 'Excite Ikki') e quatro híbridos de pepino tipo japonês ('Yoshinari', 'Kouki', 'Taisho' e 'Tsuyataro') a Meloidogyne enterolobii. O experimento foi conduzido em casa de vegetação, cada parcela constou de uma planta por vaso contendo 2 litros de solo autoclavado. Dois dias após o transplantio das mudas, cada planta foi inoculada com 5.000 ovos e juvenis de segundo estádio (população inicial = Pi) de M. enterolobii. Tomateiros 'Rutgers' foram utilizados como padrão de viabilidade do inóculo. O delineamento experimental foi inteiramente casualizado com cinco repetições por tratamento. Sessenta dias após a inoculação, cada planta foi avaliada quanto ao número total de nematoides nas raízes (população final $=\mathrm{Pf}$ ) e fator de reprodução $(\mathrm{FR}=\mathrm{Pf} / \mathrm{Pi})$. Todos os porta-enxertos e híbridos de pepino estudados permitiram a multiplicação de $M$. enterolobii, entretanto os valores do FR foram menores nos porta-enxertos 'Shelper', 'Excite Ikki KY' e 'Menina Brasileira'. Em um segundo experimento, confirmou-se o baixo valor do FR destes três porta-enxertos, porém, com valor pouco maior para 'Menina Brasileira'. Desta maneira, estes porta-enxertos podem ser recomendados em áreas infestadas com $M$. enterolobii, desde que em baixa população, por restringirem drasticamente a multiplicação do patógeno. Conclui-se que os porta-enxertos 'Shelper' e 'Excite Ikki KY' foram os que apresentaram os menores FR podendo ser classificados como moderadamente resistentes a este nematoide.

Palavras-chave: Cucumis sativus, Cucurbita moschata, Cucurbita maxima, nematoide das galhas, enxertia.

(Recebido para publicação em 27 de junho de 2012; aceito em 2 de setembro de 2013) (Received on June 27, 2012; accepted on September 2, 2013)

$\mathrm{R}$ oot-knot nematode Meloidogyne enterolobii was reported in Brazil in 2001 parasitizing roots of guava (Psidium guajava) in Northeastern Brazil, on occasion referred to as $M$. mayaguensis (Carneiro et al., 2001). In the state of São Paulo, this species was reported by Carneiro et al. (2006) in vegetable crops, specifically in rootstock of green pepper (Capsicum annuum)
'Silver' and tomatoes (Solanum lycopersicum) 'Andréa' and 'Débora', considered resistant to $M$. incognita, $M$. javanica and $M$. arenaria.

This resistance does not reach $M$. enterolobii (Rodriguez et al., 2003; Brito et al., 2007; Kiewnick et al., 2008) and due to its aggressiveness (Hussey \& Janssen, 2002), causing large production losses, this root-knot nematode species has been causing major concern in vegetable crop industry. In Brazil, Cantu et al. (2009) showed that some tomato rootstocks 'Guardião', 'Helper-M', 'Anchor-T', 'Dr. K', 'Kagemuscha', 'TMA 809', 'Magnet' and 'He-Man' ( $M i$ gene carriers), available in Brazilian market, proved to be susceptible to $M$. enterolobii. Melo et al. (2011) listed several plant species as susceptible 
to this nematode and confirmed the susceptibility of tomato plants with $\mathrm{Mi}$ and $M i-3$ genes.

The cucumber (Cucumis sativus) is one of the most affected vegetable crops with problems caused by the root-knot nematodes. Meloidogyne enterolobii was reported in cucumber cultivar Loustik in greenhouse in Switzerland (Kiewnick et al., 2008). In Brazil, susceptibility of this vegetable was proven by Bitencourt \& Silva (2010).

Grafting, depending on graft/ rootstock combination, can provide a number of improvement in traits of the cucumber plant, such as increased brightness of fruit; greater force of the canopy and, consequently increase of productivity, rootstock resistance to adverse factors, lower incidence of soil fungal diseases and nematode infection (Kawaide, 1985; Cañizares \& Goto, 1998).

Wilcken et al. (2010), studying the reproduction of $M$. incognita race 2 and $M$. javanica in rootstocks and cucumber hybrids, verified that despite all genotypes studied allow the multiplication of nematodes, the reproduction factor in rootstocks was low, suggesting the feasibility of the use of grafting on cucumber crops in areas infested by the species mentioned above.

This research aimed to determine the resistance, evaluating the reproduction factor of $M$. enterolobii in the same rootstocks and cucumber hybrids (six rootstocks and four cucumber hybrids) studied previously by Wilcken et al. (2010), in order to verify the feasibility of the use of the same rootstocks for cucumber cultivation in areas infested with this species of root-knot nematode.

\section{MATERIAL AND METHODS}

Two experiments with $M$. enterolobii were carried out separately in greenhouse, but using the same methodology. The second experiment was carried out only with genotypes which allowed low reproduction of nematode in the first experiment, to confirm the data obtained.

The pure population of M. enterolobii was isolated from the roots of the bell pepper 'Silver' originated from Campos Novos Paulista-SP, where female egg masses properly identified were removed. The multiplication of the population was carried out in roots of tomato 'Rutgers' in pots with substrates previously autoclaved, kept in greenhouse.

Eggs and any infective juveniles of M. enterolobii were extracted from the tomato roots 60 days after inoculation, following the method proposed by Hussey \& Barker (1973), modified by Bonetti \& Ferraz (1981), which is to process the infected root system in a blender with hypochlorite $0.5 \%$ and sequentially pass the processed through a set of sieves 20, 80 and 500 mesh, in order to obtain the inoculum suspension consisting of the eggs and any juveniles retained in the sieve of 500 mesh.

Six recommended squash (Cucurbita moschata) and pumpkin cultivars (Cucurbita maxima and C. maxima $\mathrm{x}$ C. moschata) were evaluated in order to be used as rootstocks for cucumber ('Menina Brasileira', 'Moranga Exposição', 'Shelper', 'Tetsukabuto Takaiama', 'B8-A Tetsukabuto' and 'Excite Ikki') and four Japanese cucumber hybrids ('Yoshinari', 'Kouki', 'Taisho' and 'Tsuyataro'), described as susceptible.

Seeds of hybrids and cultivars were sown in polystyrene trays (styrofoam) 128 cells with commercial substrate $\left(\right.$ Plantmax $\left.^{\circledR}\right)$. The seedling transplant was carried out when they showed about $5 \mathrm{~cm}$ to 2 liters pots containing substrate composed of soil, sand and manure in the ratio $1: 2: 1$, previously autoclaved.

The inoculation was carried out after two days of the seedling transplant with 5,000 eggs and second-stage juveniles of the nematode studied per pot (Initial population $=\mathrm{Pi}$ ) suspended in $2 \mathrm{~mL}$. The inoculation was carried out in two holes $2 \mathrm{~cm}$ deep, around the seedling. Five 'Rutgers' tomato plants were used as standard for inoculum viability in both experiments.

The experiments were carried out in a greenhouse, and each plot consisted of one plant per pot. The experimental design was completely randomized, with five replications per treatment.

Sixty days after inoculation, the root systems of each plot were separated from the shoots, washed and weighed after the removal of the moisture excess with the help of paper towels. Then, immersed in a floxine B solution $(0.15$ $\mathrm{g} /$ liter of water) for 15 minutes, for coloring of the external egg masses of the nematodes, which numbers were counted along with the numbers of galls, both related to the scale proposed by Taylor \& Sasser (1978). On this scale, the notes are checked $0,1,2,3,4$ and 5 the number of galls (or egg masses) is null, 1-2, 3-10, 11-30, 31-100 and $>100$, respectively.

Then, the whole root system of each plot was processed, according to the methodology of processing in blender, sieving and centrifugation as described by Coolen \& D'Herde (1972). The total number of eggs and any juveniles present (Final population $=\mathrm{Pf}$ ) was used to obtain the Reproduction Factor $(\mathrm{FR}=\mathrm{Pf} / \mathrm{Pi})$. Plants with $\mathrm{FR}$ value higher than or equal to 1.0 were classified as host plants and those that showed FR lower than 1.0, as resistant to the nematode studied (Oostenbrink, 1966).

The data obtained for FR and root fresh mass were subjected to analysis of variance and means were compared by Tukey test at $5 \%$ probability, after being transformed into $\sqrt{\mathrm{x}+0.5}$.

Gall and egg mass indexes traits are just indicative of infection and multiplication of nematodes in the root systems, being FR the most important trait in the definition of the genotype susceptibility for quantitative comparison of nematode reproduction among plants.

\section{RESULTS AND DISCUSSION}

The tomato 'Rutgers' provided FR equals to 40.11 and 20.64 in the first and second experiments, respectively, proving the viability of the inoculums used in both experiments.

In the first experiment, high number of galls (IG) and egg masses (IMO) were observed, IG ranging from 3.8 for 'Excite Ikki KY' rootstock to 5.0 for hybrids 'Tetsukabuto Takaiama', 'Taisho KY', 'Tsuyataro', 'Yoshinari' and 'Kouki' (Table 1). IMO ranged from 3.2 for 'Shelper' rootstock to 5.0 
Table 1. Gall index (IG), egg mass index (IMO), final population of nematode in roots (Pf) and reproduction factor (FR) of Meloidogyne enterolobii in different cucumber hybrids and rootstocks [índice de galhas (IG), índice de massa de ovos (IMO), população final do nematoide (Pf) e fator de reprodução (FR) de Meloidogyne enterolobii em diferentes híbridos de pepino e porta-enxertos]. Botucatu, UNESP, 2009.

\begin{tabular}{|c|c|c|c|c|c|c|c|c|c|c|c|}
\hline \multirow{2}{*}{ Treatments } & \multicolumn{5}{|c|}{$1^{\text {st }}$ experiment } & \multicolumn{5}{|c|}{$2^{\text {nd }}$ experiment } & \multirow{2}{*}{ Reaction $^{* *}$} \\
\hline & IG & IMO & Pf & FR & & action & IG & IMO & Pf & FR & \\
\hline Ab. 'Shelper' & 4.5 & 3.2 & $5031 \mathrm{a}$ & 1.01 & & $\mathrm{~S}^{*}$ & 4.8 & 3.0 & $5036 \mathrm{a}$ & $1.01 \mathrm{a}$ & $\mathrm{S}^{*}$ \\
\hline Ab. 'Excite Ikki KY' & 3.8 & 3.7 & 5860 a & 1.17 & & $\mathrm{~S}^{*}$ & 4.0 & 3.0 & $5051 \mathrm{a}$ & $1.01 \mathrm{a}$ & $\mathrm{S}^{*}$ \\
\hline Ab. 'Menina Brasileira' & 4.8 & 4.2 & $17840 \mathrm{ab}$ & 3.57 & & $\mathrm{~S}$ & 5.0 & 4.4 & $23542 \mathrm{~b}$ & $4.71 \mathrm{~b}$ & $\mathrm{~S}$ \\
\hline Ab. 'B8-A Tetsukabuto’' & 4.5 & 3.5 & $37817 a b c$ & 7.56 & $a b$ & $\mathrm{~S}$ & - & - & - $\quad-$ & $-\quad-$ & - \\
\hline Ab. 'Tetsukabuto Takaiama' & 5.0 & 4.0 & $63545 \mathrm{abc}$ & 12.71 & $a b$ & S & - & - & - & - & - \\
\hline Pep. Japonês 'Taisho KY' & 5.0 & 5.0 & $76411 \mathrm{abc}$ & 15.28 & $a b$ & $\mathrm{~S}$ & - & - & - & - & - \\
\hline Ab. Moranga 'Exposição' & 4.8 & 4.8 & $90636 \mathrm{abc}$ & 18.13 & $a b$ & S & - & - & - & - & - \\
\hline Pep. Japonês 'Tsuyataro' & 5.0 & 5.0 & $116450 \mathrm{bcd}$ & 23.29 & $a b c$ & S & - & - & - & - & - \\
\hline Pep. Japonês 'Yoshinari' & 5.0 & 5.0 & $186071 \mathrm{~cd}$ & 37.21 & $\mathrm{bc}$ & S & - & - & - & - & - \\
\hline Pepino Japonês 'Kouki' & 5.0 & 5.0 & $423007 \mathrm{~d}$ & 84.60 & $\mathrm{c}$ & $\mathrm{S}$ & - & - & - & - & - \\
\hline CV $(\%)$ & & & 52.49 & 50.46 & & & & & 22.57 & 16.12 & \\
\hline
\end{tabular}

${ }^{1}$ Means followed by the same letter at column did not differ from each other by Tukey test at $5 \%$ of probability (médias seguidas pela mesma letra na coluna não diferem entre si, pelo teste de Tukey, a $5 \%$ de probabilidade). According to Oostembrink's criterion (1966), those cultivars are susceptible, although they may be considered moderately resistant by its low values of FR and have not been detected other sources of resistance presenting FR lesser than one [dados transformados em $\sqrt{\mathrm{x}+0,5}$. ( $\mathrm{S}=$ Suscetível, $\mathrm{R}=\mathrm{Resistente)}$ ) *Pelo critério de Oostembrink (1966), tais cultivares são suscetíveis, embora possam ser consideradas medianamente resistentes pelos baixos valores do FR e por não terem sido ainda detectadas outras fontes de resistência com FR menor que um].

for hybrids 'Tetsukabuto Takaiama', 'Taisho KY', 'Tsuyataro', 'Yoshinari' and 'Kouki'.

The 'Shelper' (FR 1.01), 'Excite Ikki KY' (FR 1.17) and 'Menina Brasileira' (FR 3.57) rootstocks provided lower reproduction of $M$. enterolobii than the cucumber hybrids Yoshinari (FR 37.21) and Kouki (FR 84.60), which provided high values for FR. However, according to Oostenbrink (1966), all of them are considered susceptible, because they showed reproduction factor (FR) higher than 1.0. Thus, these results do not confirm Miguel (1997), Oda (1995) and Goto et al. (2003) reports which states that the rootstocks which have been used are resistant to root-knot nematodes. However, these authors present these statements without showing any research results.

In general, the cucumber hybrids allowed higher $M$. enterolobii reproduction than the rootstocks, following the same trend observed by Wilcken et al. (2010) for M. javanica. Bitencourt \& Silva (2010) also obtained high rate of $M$. enterolobii reproduction in 'Caipira Esmeralda' cucumber $(\mathrm{FR}=12.9)$ and relatively low rate for pumpkin (Cucurbita moschata)
'Maranhão' (FR=1.5).

The cucumber hybrids Tsuyataro, Yoshinari and, mainly, Kouki showed the highest values for root fresh mass, higher than the pumpkin 'Shelper' and 'Excite Ikki KY'. This result may be related to the reaction of the cucumber plant to the great reproduction of this nematode species, with higher emission of roots and high number of galls. Also Wilcken et al. (2010) and Salata et al. (2012) reported this same trend in cucumber infected with $M$. javanica.

When comparing only the three pumpkins which can be used as rootstocks, in the second experiment, the authors observed that 'Menina Brasileira' allowed higher nematode reproduction in relation to 'Shelper' and 'Excite Ikki KY' (Table 1). In this experiment, low reproduction for $M$. enterolobii in 'Shelper' and 'Excite Ikki KY' was proved, with FR of only 1.01, value that ranks them, in the limit, as susceptible, according to Oostenbrink (1966). However, according to the criteria described by Roberts (2002), the plants which provide lower nematode reproduction can be considered hosts, but partially resistant when compared to the ones which allow greater reproduction.
According to Starr \& Roberts (2004), genetic resistance, besides being an important tool for crop management, is also advantageous because it does not allow the nematode multiplication, or at least, it reduces the multiplication, also helping out the next crop. It is what happens when these rootstocks, which makes it difficult the nematode reproduction, is used. So, it is practical utility as a control measure.

The adoption of grafted cucumber seedlings in areas infested with gall nematodes positively interferes in quality and productivity of the crop, as verified by Cañizares \& Goto (1998), Goto et al. (2003) and Salata et al. (2012). Considering the absence of resistant commercial cultivars, 'Shelper' and 'Excite Ikki KY' rootstocks can be recommended in areas infested with low population of this species of nematode. However, it is important to highlight that although the reproduction factors in these rootstocks have been lower than in the other rootstocks and cucumbers studied, these were not null, and they may raise the population if they are grown successively.

The authors concluded that 'Shelper' and 'Excite Ikki KY' rootstocks were the 
ones which showed the lowest FR and they can be ranked as partially resistant to M. enterolobii.

\section{ACKNOWLEDGEMENTS}

To the Fundação de Amparo à Pesquisa do Estado de São Paulo (FAPESP) for financial support.

\section{REFERENCES}

BITENCOURT NV; SILVA GS. 2010. Reprodução de Meloidogyne enterolobii em olerícolas. Nematologia Brasileira 34: 181-183.

BONETTI JI; FERRAZ S. 1981. Modificações do método de Hussey \& Barker para extração de ovos de Meloidogyne exigua em raízes de cafeeiro. Fitopatologia Brasileira 6: 553.

BRITO JA; STANLEY JD; KAUR R; CETINTAS R; VITO MD; THIES JÁ; DICKSON DW. 2007. Effects of the Mi-1, N and Tabasco genes on infection and reproduction of Meloidogyne mayaguensis on tomato and pepper genotypes. Journal of Nematology, 39: 327-332.

CAÑIZARES KAL; GOTO R. 1998. Crescimento e produção de híbridos de pepino em função da enxertia. Horticultura Brasileira 16: 110-112.

CANTU RR; WILCKEN SRS; ROSA JMO; GOTO R. 2009. Reação de porta-enxertos de tomateiros a Meloidogyne mayaguensis. Summa Phytopathologica 35: 124-126.

CARNEIRO RMDG; ALMEIDA MRA; BRAGA RS; ALMEIDA CA; GIORIA R. 2006. Primeiro registro de Meloidogyne mayaguensis parasitando plantas de tomate e pimentão resistentes a meloidoginose no estado de São Paulo. Nematologia Brasileira 30: 81-86.

CARNEIRO RMDG; MOREIRA WA; ALMEIDA MRA; GOMES ACMM. 2001. Primeiro registro de Meloidogyne mayaguensis em goiabeira no Brasil. Nematologia Brasileira 25: 223-228.

COOLEN WA; D'HERDE CJ. 1972. A method for quantitative extraction of nematodes from plant tissue. Merebelke: State Nematology Research Station. 77p.

GOTO R; SANTOS HS; CAÑIZARES KAL. 2003. Enxertia em hortaliças. São Paulo: Editora UNESP. 85p.

HUSSEY RS; BARKER KR. 1973. A comparison of methods colleting inocula of Meloidogyne spp. including a new technique. Plant Disease Reporter 57: 1025-1028.

HUSSEY RS; JANSSEN GJW. 2002. Rootknot nematode: Meloidogyne species. In: STARR JL; COOK R; BRIDGE J (eds) Plant resistance to parasitic nematodes. CAB International. Wallingford, UK. 43-70.

KAWAIDE T. 1985. Utilization of rootstocks in cucurbits production in Japan. Japanese Agricultural Research Quarterly 18: 285-288.

KIEWNICK S; KARSSEN G; BRITO JA; OGGENFUSS M.; FREY JE. 2008. First report of root-knot nematode Meloidogyne enterolobii on tomato and cucumber in Switzerland. Plant Disease 92: 1370.

MELO OD; MALUF WR; GONÇALVES RJS; GONÇALVES NETO AC; GOMES LAA; CARVALHO RC. 2011. Triagem de genótipos de hortaliças para resistência a Meloidogyne enterolobii. Pesquisa Agropecuária Brasileira 46: 829-835.

MIGUEL A. 1997. Injerto en hortalizas.
Generalitat Valenciana, Conselleria de Agricultura, pesca y alimentación, 88 p.

ODA M. 1995. New grafting methods for fruit-bearing vegetables in Japan. Japanese Agricultural Research Quarterly 29: 187-194.

OOSTENBRINK M. 1966. Major characteristics of the relation between nematode and plants. Meded. Landbouwhogeschool 66: 3-46.

ROBERTS PA. 2002. Concepts and consequences of resistance. In: STARR JL; COOK R; BRIDGE J (eds). Plant resistance to parasitic nematodes. CAB International, Wallingford, UK, 23-42.

RODRIGUEZ MG; SANCHEZ L; ROWE J. 2003. Host status of agriculturally important plant families to the root-knot nematode Meloidogyne mayaguensis. Nematropica, 3: 125-130.

SALATA AC; BERTOLINI EV; MAGRO FO; CARDOSO AII; WILCKEN SRS. 2012. Enxertia e sua influência na produção de pepino e reprodução de Meloidogyne javanica e M. incognita. Horticultura Brasileira 30: 590-594.

STARR JL; ROBERTS PA. 2004. Resistance to plant parasitic nematodes. In: CHEN ZN; CHEN SY; DICKSON DW (eds). Nematology, Advances and Perspectives, vol.2. Nematode Management and Utilization. CAB International, Wallingford, UK, 879-907.

TAYLOR AL; SASSER JN. 1978. Biology, identification and control of root-knot nematodes (Meloidogyne species). Raleigh, North Carolina State University. 111p.

WILCKEN SRS; ROSA JMO; HIGUTI ARO; GARCIA MJM; CARDOSO AII. 2010. Reprodução de Meloidogyne spp. em portaenxertos e híbridos de pepino. Horticultura Brasileira 28: 100-103. 